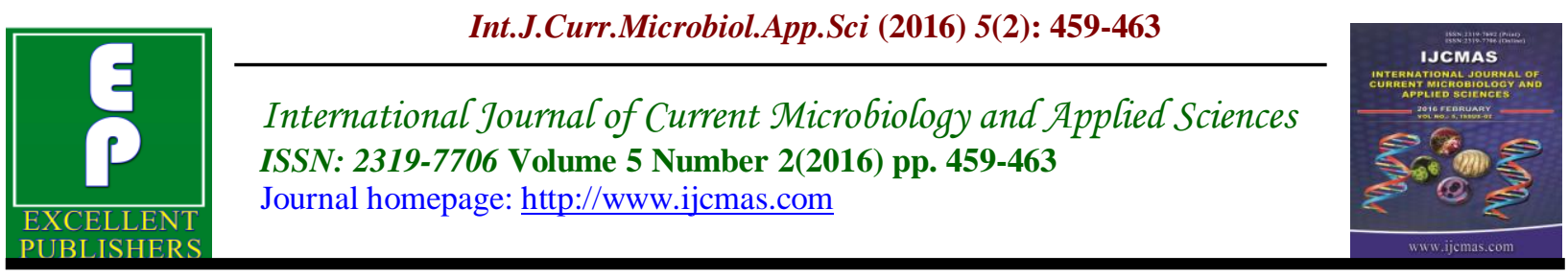

Original Research Article

doi: http://dx.doi.org/10.20546/ijcmas.2016.502.051

\title{
The Antibacterial Effect of some Household Detergents against Staphylococcus aureus
}

\author{
Mohamed M. Jouda ${ }^{1}$, Zuhair Dardona ${ }^{2}$ and Mohammed Albayoumi ${ }^{3}$ \\ ${ }^{1}$ Department of Microbiology, College of Intermediate Studies, Al-Azhar University of Gaza, Palestine \\ ${ }^{2}$ Department of Microbiology, Medical services, Gaza, Palestine \\ ${ }^{3}$ Department of Microbiology, Ministry of Agriculture, Veterinary services, Gaza, Palestine \\ *Corresponding author
}

Keywords

Detergents,

Dettol and

Clorex

Article Info

Accepted:

06 December 2015

Available Online:

10, January 2016

\section{A B S T R A C T}

\section{Introduction}

Health is one of the most important factors in human life. Contracting an illness can be bad, and can even cause death. Over the years, rather than using antimicrobial drugs, antiseptics and disinfectants have played important roles in the control of infectious disease, microbial food spoilage and unwanted microbial generally (Awodele et al, 2007).

Using a disinfectant detergent that will effectively kill harmful bacteria can help people stay healthy. Detergents are substances, it could be liquid, solid or semi solid, which are used to remove dirt, stains and microorganisms in order to maintain health (Moses et al, 2013 and Wang et al, 2012).
These disinfectants cause distraction of microorganisms by two variables: the concentration of the detergent and the length of time the detergent is applied (Levinson, 2012).

For many years, hand washing with soap and water had been considered a measure of personal hygiene.Bacteria are very diverse and present everywhere such as in soil, water, sewage, standing water and even in human body. Bacteria's that attacks on human body is of great importance with reference to health (Bhat et al, 2011).

Foodborne diseases affect human by ingestion or drinking contaminated water with specific microorganisms, these 
microorganisms may be ingested directly or indirectly. One way of indirect infections is using contaminated kitchen utensils, Staphylococcus mainly $S$. aureus causes foodborne gastroenteritis. The symptoms of staphylococcal food poisoning usually develop within 4 hours of the ingestion of contaminated food, although a range of 1 hours has been reported. The symptoms include nausea, vomiting, abdominal cramps, diarrhea, sweating, headache and prostration (Jay et al, 2005). In order to prevent infection it's highly important to use trusted detergents that kill pathogenic microorganism.

This study was done to evaluate the effectiveness of some cleaning products that widely used in homes and healthcare settings by determining how effective they are in inactivate one of the most commonly encountered pathogenic microbes in day to day activities, Staphylococcus aureus.

\section{Materials and Methods}

\section{Source of Detergents and their Constituent}

Each of the following detergents (Table 1) was obtained from a local market, Gaza, Palestine.

\section{Inoculation of the Test Organisms}

S. aureus was obtained and confirmed at microbiology laboratory of the Islamic University of Gaza. Bacteria colonies were maintained on Mueller-Hinton Agar medium (Himedia, India). Twenty-four hour old pure cultures were prepared for use each time.

\section{Preparation of the Disinfectants}

Disinfectants from the original packages were considered to be absolute concentration (100\%). Using sterile distilled water, serial dilutions of each of the disinfectant were prepared to obtain $50 \%$ and $25 \%$ concentrations.

\section{Preparation of Sterile Disc}

Filter disks about $5 \mathrm{~mm}$ in diameter were made from Whatman's No.3 filter paper and wrapped in aluminum foil and sterilize in an oven at $75 \mathrm{oC}$ for 30 minutes. Each sterile disc was incorporated individually with 40 $\mu 1$ of detergent with various concentrations (25\%, 50\% and $100 \%)$. These discs were allowed for air drying.

\section{Assay of Antimicrobial Activity}

Using sterile forceps, discs impregnated with different dilution and different disinfectants were placed on each of the plates inoculated with the test organisms. The forceps was used to press down each of the disc gently against the agar surface so as to ensure good contact. The plates were incubated in an inverted position at $37 \mathrm{oC}$ for 24 hours. The zones of inhibition were observed, and then measured accurately (Okore et al, 2014).

\section{Results and Discussion}

Commercial products of four detergents (Dettol ${ }^{\circledR}$, Clorex ${ }^{\circledR}$, Elrajeh $\AA$ and Jett $\left.{ }^{\circledR}\right)$ were used with three concentrations $100 \%$, $50 \%$ and $25 \%$.

After 24 hours of cultivation, inhibition zones were measured. All detergents showed considerable antimicrobial activity. The results show that $S$. aureus vary in its response to different types of antiseptics and detergent. Elrajih ${ }^{\circledR}$ was the least effective one. On the other hand, Dettol ${ }^{\circledR}$ was found highly effective against $S$. aureus where the zones of inhibition ranged from $25 \mathrm{~mm}$ to 37 $\mathrm{mm}$ (Fig.1). The zones of inhibition exhibited by the detergents with their 
dilutions against $S$. aureus are shown in table 2.

The effect of Dettol® was assessed by (ElMahmood and Doughari, 2008) against some microorganisms associated with nosocomial infection including $S$. aureus, it was highly effective like this study results, results of this study regarding Dettol $®$ are similar to that obtained by (Saha et al, 2009) as the study recorded inhibition zones ranging from 28 to $17 \mathrm{~mm}$ for $100 \%$ to $5 \%$ concentration. The results proved that the antibacterial effects of antiseptics and disinfectants are not only dependent on the types of antiseptics and disinfectant but also on their concentrations. Sodium hypochlorite has a good activity against S.aureus, and it is the most used antiseptic compound in homes cleaning, (Lee et al, 2009) concluded from this study that the optimum washing and sanitizing conditions for lettuce containing $S$. aureus using sodium hypochlorite are depending on concentration, period of immersion and temperature.

Table.1 The Main Chemical Constituent of Detergents

\begin{tabular}{|c|c|}
\hline Detergents & Chemical constituent \\
\hline 1. Dettol ${ }^{\circledR}$ & $\begin{array}{l}\text { Chloroxtlenol 4.85\% w/w, Pine oil, Isopropyl } \\
\text { Alcohol, Castor Oil, Caramel and Deionized Water. }\end{array}$ \\
\hline 2. Clorex $^{\circledR}$ & Sodium hypochlorite $12 \%$. \\
\hline 3. Elrajeh $^{\circledR}$ & $\begin{array}{l}\text { Sodium alkyl benzene sulphonate and coconut } \\
\text { diethanol amide }(12 \%) \text { concentration. }\end{array}$ \\
\hline 4. Jett ${ }^{\circledR}$ & Chloroxylenol $1.2 \%$ \\
\hline
\end{tabular}

Table.2 Zone of Inhibition Produced by the used Four Detergents

\begin{tabular}{|c|c|c|c|}
\hline Detergents & $\begin{array}{c}100 \% \\
\text { Inhibition zone } \\
(\mathrm{mm})\end{array}$ & $\begin{array}{c}50 \% \\
\text { Inhibition zone } \\
(\mathrm{mm})\end{array}$ & $\begin{array}{c}\mathbf{2 5} \% \\
\text { Inhibition zone } \\
(\mathrm{mm})\end{array}$ \\
\hline A-Dettol $^{\circledR}$ & 37 & 28 & 25 \\
\hline B- Clorex ${ }^{\circledR}$ & 25 & 17 & 15 \\
\hline C- Elrajeh ${ }^{\circledR}$ & 13 & 10 & 7 \\
\hline D- Jett ${ }^{\circledR}$ & 21 & 15 & 11 \\
\hline
\end{tabular}


Fig.1 The Diameter of the Zones of Inhibition after 24 Hours. A= Dettol@, $\mathrm{B}=$ Clorex ${ }^{\circledR}, \mathrm{C}=$ Elrajeh ${ }^{\circledR}$ and $\mathrm{D}=\mathrm{Jett}{ }^{\circledR}$

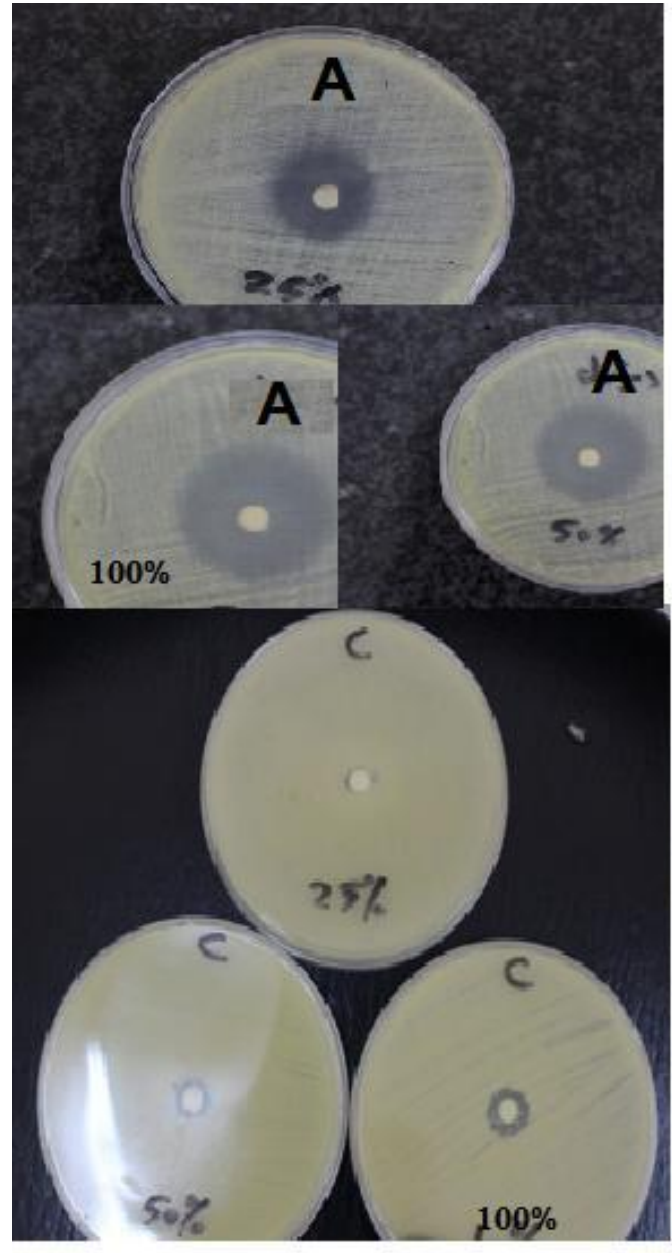

\section{References}

Awodele O, Emeka P, Agbamuche $\mathrm{H}$ and Akintonwa A. The Antimicrobial Activities of Some Commonly used Disinfectants on Bacillius subtilis, Pseudomonas aeruginosa and Candida albicans. African Journal of Biotechnology. 16 April 2007; Vol. 6 (8): 987- 990.

Bhat R, Prajna S, Menezez P and Shetty P. (2011). Antimicrobial activities of soap and detergents. advances in bioresearch. December 2011; Vol. 2, (2): 52-62.
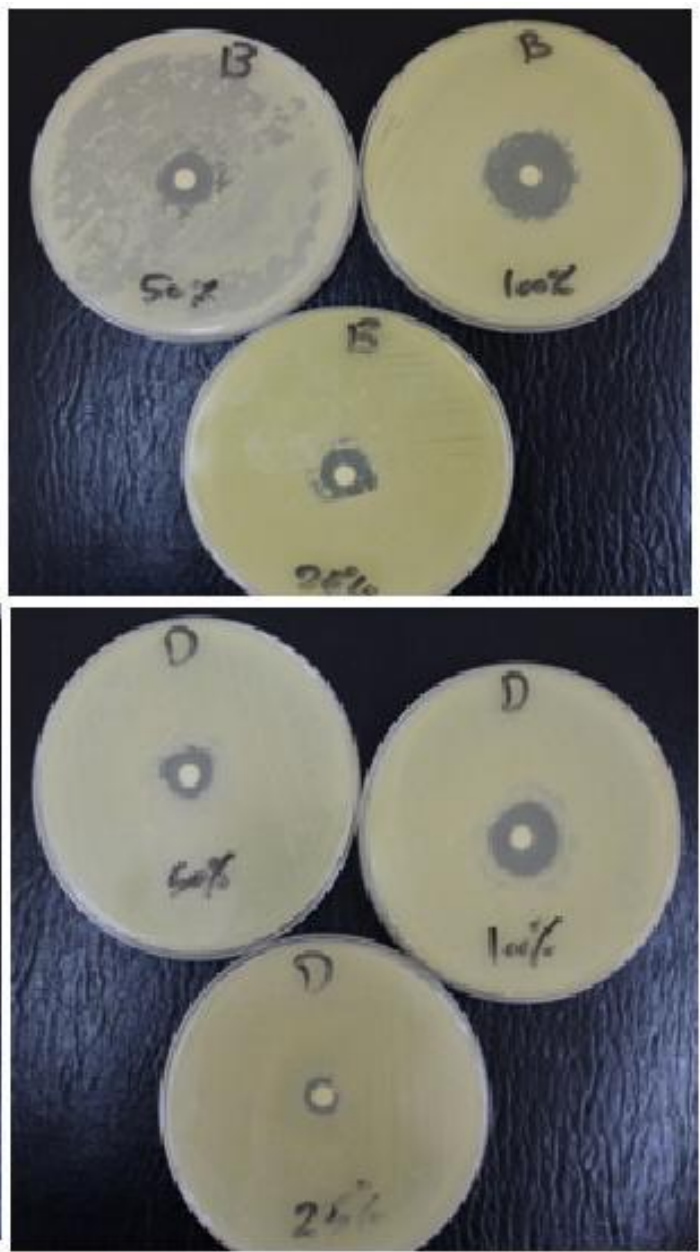

El Mahmood M and Doughari J. Effect of Dettol ${ }^{\circledR}$ on viability of some microorganisms associated with nosocomial infections. African Journal of Biotechnology. 2008; Vol. 7, (10).

Jay M, Loessner M, and Golden D. Modern Food Microbiology Modern Food Microbiology. (2005).

Lee Y, Jo S, Cho S, Kim G, Kim Y, Lee D, Park S, Bae D, Chung M, Bahk G and Ha D.. Effects of chlorine concentrations and washing conditions on the reduction of microbiological contamination in lettuce. Journal of the Korean Society for Applied Biological 
Chemistry. 2009; Vol. 52, (3): 270274.

Moses I, Rosemary M, Linda A and Nsikak A. Antimicrobial activity of some cleaning products against selected bacteria. International Research Journal of Pharmaceutical and Applied Sciences (IRJPAS). 2013; Vol. 3, (4): 175-179.

Okore C, Mbanefo O, Onyekwere B, Onyewenjo S, Ozurumba A and AbbaFather. Antimicrobial Efficacy of Selected Disinfectants. American Journal of Biology and Life Sciences. 2014; Vol. 2, (2): 53.
Review of Medical Microbiology and Immunology (2012). Warren Levinson. Twelfth Edition. page 100.

Saha AK, Haque MF, Karmaker $S$ and Mohanta MK. Antibacterial effects of some antiseptics and disinfectants. Journal of Life and Earth Science. 2009; Vol. 3: 19-21.

Wang Z, Shen Y, Ma J and Haapasalo M. The effect of detergents on the antibacterial activity of disinfecting solutions in dentin. Journal of endodontics. 2012; Vol. 38, (7): 948953.

\section{How to cite this article:}

Mohamed M. Jouda, Zuhair Dardona and Mohammed Albayoumi. 2016. The Antibacterial Effect of some Household Detergents against Staphylococcus aureus. Int.J.Curr.Microbiol.App.Sci. 5(2): 459-463. doi: http://dx.doi.org/10.20546/ijcmas.2016.502.049 